\title{
A Review on Finite Element Analysis of Beam to Column Endplate Bolted Connection
}

\author{
Kuldeep Kaushik ${ }^{1}$, Avadesh K. Sharma ${ }^{2}$, Rishi Kumar ${ }^{3}$ \\ ${ }^{1}$ Research Scholar, ${ }^{2}$ Asst. Prof., Department Of Mechanical Engineering, Madhav Institute of Technology \& \\ Science, Gwalior (M.P.)- 474005, India. \\ ${ }^{3}$ Visiting Faculty, Department Of Mechanical Engineering, The M. S. University of Baroda, Vadodara \\ (Gujarat) - 390002, India.
}

\begin{abstract}
This paper gives a bibliographical review of the methods which are applied for the analysis of Beam to column bolted end plate connection from the theoretical as well as practical points of view. The bibliography at the end of the paper contains 84 references of papers and conference proceedings on the subject that were published between 1914 and 2011. These are classified in the following categories:

- Conventional methods like experimental, empirical, analytical, mechanical, informational and other methods.

- $\quad$ Finite Element Method(s) (FEM) using different software like ANSYS, ABACUS etc.

Keywords : Beam to Column bolted Endplate Connection and FEM.
\end{abstract}

\section{Introduction}

The output of scientific papers in general is fast growing and professionals are no longer able to be fully up-to-date with all the relevant information. The increasing specialization in various engineering fields has resulted in the proliferation of subject-oriented journals and conference proceedings directed to specialist audiences. The researchers have more channels for communicating the results of their research at their disposal, but on the other hand finding the necessary information may be a time-consuming and uneasy process. Another question is whether researchers/ scientists are willing to spend time looking for information. It has been pointed out that in engineering, informal knowledge channels are the most frequently used means of obtaining information. In the last almost four decades the finite element method (FEM) has become the prevalent technique used for analyzing physical phenomena in the field of structural, solid, and applied mechanics as well as for the solution of field problems. Connections form an important part of any structure and are designed more conservatively than members. This is because, connections are more complex than members to analyze, and the discrepancy between analysis and actual behavior is large. Combinations of simple fabrication techniques and speedy site erection have made bolted endplate connection is one of the most popular methods of connecting members in structural steelwork frames. Although it is simple in their use, bolted endplates are extremely complex in their analysis and behavior. Bolted joints are often the most critical parts with respect to fatigue life of structures. Therefore, it is important to analyze these components and the forces they are subjected to.

Bolted connections, especially end-plate types, are being widely used in steel structures. They are often used as moment-resistant connections. They have the advantages of easy quality control and less assembly time than welded connections. These connections include two types: flush end-plate connections and extended endplate connections with or without stiffeners.

The behavior of beam-to-column connection in structural steel frames can be conveniently represented by its flexural behavior which is primarily shown by the moment-rotation $(\mathrm{M}-\phi)$ relationship. This behavior is non-linear even at low load levels. In fact, moment-rotation curves represent the result of a very complex interaction among the elementary parts constituting the connection.

This paper concentrates mainly on the different methods used to analyze the joint behavior of a bolted connection in the mechanical structures like Bridges, Shade structures etc. The bibliography is divided into the following parts and concerns:

- Conventional Method(s).

- FEM using Software.

The bibliography is organized into two main parts. In the first, each topic is handled and current trends in modelling techniques are mentioned. The second part, Appendix A, contains a list of papers published in the open literature in the period of 1914-2011 on subjects listed above. Hopefully, this bibliography will save time for readers looking for information on finite element analyses of Beam to column bolted connection in the structural steel work. A more detailed discussion against it is given in Ref. [19], in which there are more 180 citations are referred. 


\section{Finite Element Analysis Of Beam To Column Endplate Connection}

\subsection{Conventional Method(S)}

Steel portal frames were traditionally designed assuming that beam-to-column joints are ideally pinned or fully rigid. This simplifies the analysis and structural design processes; but at the expense of not obtaining a detailed understanding of the behavior of the joints, which have a finite stiffness and are semi-rigid. The last century saw the evolution of analysis methods of semi-rigid joints, from the slope deflection equations [1] and moment distribution methods [2], to the matrix stiffness methods [3-5] and nowadays, iterative methods coupling the global structural analysis with the analysis of the joint [6-8]. Studies agree that in frame analysis, the joint rotational behavior should be considered [5-6, 9]. This is commonly done by using the momentrotation curve. Numerical models based on the Finite Element Method (FEM), can be used to determine the mechanical behavior of joints. These models started to be used for several reasons:

1) As a means of overcoming the lack of experimental results;

2) To understand important local effects which can be difficult to measure experimentally with sufficient accuracy, e.g. prying and contact forces between the bolt and the connection components;

3) To generate extensive parametric studies; and

4) To determine the rotational behavior of a joint.

Other models which can be used are: experimental [10], empirical [11], analytical [12-13], mechanical [14-16] and informational [17-18]. A more detailed discussion of these is given in Ref. [19]. Despite numerous years of extensive research [20], particular in the 1970's, no fully agreed design method exists. Many areas of connection behavior still require investigation.

Conventional methods of steel frame analysis use two idealized connection models: either the rigidjoint model or the pinned-joint model. Because the actual behavior of frame connections always falls in between these two extremes, much attention has been focused in recent years toward a more accurate modeling of such connections [21]. So the moment-rotation $(M-\theta)$ behavior of connections has been studied deeply, which is necessary if the effects of connections are to be considered in structural analysis.

Many tests of beam-column connections have been performed [20]. But the practical connection types and sizes are numerous, especially the bolted end-plate connection, because of its innate characteristics of geometry details and assembly technology, it has many variable parameters, for example: bolt diameter, number of bolt rows and columns, vertical and horizontal bolt spacing, bolt grade, end-plate thickness, extension of endplate beyond and below beam flange, end-plate width, end-plate stiffener, column stiffener, dimensions of beams and columns, bolt pretension force, yield strength of steel, slip coefficient of contact surfaces between end-plates, etc, so it is almost impossible to study its $M-\theta$ behavior only by tests.

Moment rotation $(M-\theta)$ characteristics of bolted or bolted/welded steel connections are indicative of the connection's stiffness, strength, and ductility. Experimentally obtained $M-\theta$ behavior is entirely dependent upon and highly sensitive to the connection's geometric variables (i.e., plate/angle thickness, bolt diameter, bolt pitch, bolt gauge, etc.). Studies relating to rotational stiffness of beam-to-column connections historically go back to early 1900. Wilson and Moore [22] conducted several tests to establish the relationship between moments and relative rotations of beam-column connections. Prior to 1950, riveted connections were tested by Rathbun [23]. Next, the use of high-strength bolts as structural fasteners was tested by Bell et al. [24]. Douty and McGuire [25] reported the importance of end-plate thickness on the strength of connections based on a limited test series of five flush end-plate connections. Subsequently, the behavior of header plate connections was experimentally investigated by Sommer [26]. Since the late 1960s, flush end-plate and extended end-plate connections for use as moment connections have been investigated extensively by Ostrander [27] and Johnstone and Walpole [28], respectively. Srouji et al. [29] conducted several experimental testing and yield line analyses on flush end-plate connections with one and two rows of bolts below the tension flange. In this study yield line analysis closely predicted the strength of the connection. Azizinamini and Radziminski [30] performed 18 static tests on top and seat flange angles and double web angle connections. It was shown that the geometric parameters significantly affected the $M-\theta$ performance. Several researchers have proposed experimentally based theoretical and mathematical models to represent the $M-\theta$ behavior of the tested connections. Many research projects have been carried out in the past few decades to classify the connection types and to develop the mathematical model for connection stiffness. Frye and Morris [31] collected 145 test data and classified seven types of connection tests ranging from the weakest single web angle connection to the stiffest $\mathrm{T}$-stub connection. They modeled the $M-\theta$ relationship by a polynomial function which was previously adopted by Sommer [26]. Ang and Morris [32] collected $32 M-\theta$ results from experiments, conducted from 1934 to 1976, and grouped into five types, namely the single web angle, the double web angle, the header plate, the top and seat angle and the strap angle connections. The Ramberg-Osgood function presented by Ramberg and Osgood [33] was used to represent the standardized moment-rotation relationship for the five commonly used connection types. Packer and Morris [34], Zoetemeiijer [35], and Phillips and Packer [36] utilized straight and curved yield line 
mechanisms to predict end-platemoment capacity in flush end-plate connections. Bijlaard and Zoetemeiijer [37] conducted studies on semi-rigid frames and concluded that a complete classification of semi-rigid connections must take into account the ratio between the connection stiffness and the beam stiffness. Bjorhovde et al. [38] concluded that the framework and its members and connections exhibit semi-rigid nonlinear response characteristics. They also reported that connection flexibility can produce significantly larger second-order $P-\triangle$ effects in the structure that must be accounted for in the design. Bjorhovde et al. [39] developed a scheme to classify connections using test and theoretical data. This scheme uses stiffness, ultimate strength, and ductility requirements, which is applicable to old and new connections. Barakat and Chen [40] incorporated connection stiffness considerations into the established AISC-LRFD design approach using two proposed connection models. The first model uses a modified initial stiffness representation and the second model is determined by the beam-line method. $\mathrm{Xu}$ et al. [41] used empirical data to represent the stiffness of partially restrained (PR) connections. However, the resulting moment-rotation curves offered little practical value to the designer, since connection behavior (i.e. strength and stiffness) is highly dependent on the connecting members. Yee and Melchers [42] developed mathematical equations for end-plate moment connections using experimentally obtained data. Kishi and Chen [43-44] extended the collection of the steel connection $M-\theta$ data to include results from $300+$ tests, classified into seven connection types. They introduced several $M-\theta$ models, of which the Three-Parameter Power model gained most attention. Stark and Bijlaard [45] introduced simplified methods to develop bilinear models to represent typical nonlinear $M-\theta$ curves. This study showed that extended moment end-plate connections can be designed to provide ductility in seismic force resisting moment frames.

\subsection{Finite Element Method(S) Using Software}

The first study into joint behaviour using FEM, Bose et al. [46], related to welded beam-to-column joints, which included: plasticity, strain hardening and buckling. The majority of Finite Element (FE) models found in the literature, however, only analyse bolted joints, the most relevant of which are discussed next. Krishnamurthy and Graddy [47] made the first three-dimensional (3D) joint model. Sherbourne and Bahaari [48] developed a model to investigate the behaviour of steel bolted end-plate connections. Bursi and Jaspart modelled T-stub connections [49] and isolated extended end-plate connections [50-51]. Choi and Chung [52] presented a 3D model of a double extended endplate, which included the column flange; Bahaari and Sherbourne [53] developed a detailed 3D model to study 8-bolt unstiffened extended end-plate connections; Sumner et al. [54] also used 3D models to develop 4 and 8-bolt extended unstiffened end-plate connections; Swanson et al. [55] used 3D and several two-dimensional (2D) models to study the behaviour of T-stub flanges; Citipitioglu et al. [56] presented different 3D models of bolted connections with angles, following the recommendations of Ref. [51] on the FE selection. Gantes and Lemonis [57] developed a model for bolted Tstub steel connections. Ju et al. [58] developed a 3D model to study the structural behaviour of butt-type steel bolted joints. Tagawa and Gurel [59] used FE simulations to examine the strength of steel beam-to-column joints stiffened with bolted channels. Abolmaali et al. [60] developed a 3D model for flush end-plate connections.Maggi et al. [61] carried out parametric analyses on the behaviour of bolted extended end-plate connections using 3D models. Kukreti and Zhou [62] quantified the impact of semi-rigid connection properties on steel frame behaviour, and developed a 3D FE model and computer program to investigate the momentrotation behaviour of eight-bolt stiffened end-plate connections. Pirmoz et al.[63] studied the behaviour of bolted top-seat angle connections with web angles using several 3D parametric models. Dai et al. [64] made a simulation study of 10 fire tests on restrained steel beam-column assemblies using five different types of joints: fin plate, flexible endplate, flush end-plate, web cleat and extended end-plate. Krishnamurthy was the pioneer in the field of 3D modeling of connections, by adopting eight-node sub-parametric bricks in order to reproduce the behavior of bolted end plate connections [65]. The analyses carried out were linearly elastic but expensive, because contact was embodied artificially by attaching and releasing nodes at each loading step on the basis of the stress distribution. Bolt preloading phenomena were simulated also. Then, a correlation between twodimensional (2D) and 3D finite element analyzes was established and a parametric study was conducted with 2D models, owing to the limited computer capabilities. A similar procedure was proposed by Kukreti et al. [66] in order to reproduce moment-rotation relationships of end plate connections. The results of these analyses were useful in the range for which such validations were performed. However, fundamental issues relating to the number of integration points, kinematic description, element type and discretization were not investigated. Kukreti et al. [67] also developed finite element models for stiffened steel tee-hanger connections. These models can be classified as hybrid since they encompassed solid elements for both plates and bolts and plane elements for both web and stiffeners. Satisfactory results were obtained using these models. Nevertheless, some basic issues like discretization and type of yield criterion were faced up. Researchers used 3D finite element models based either on shell and separator truss elements [68] or shell and contact elements [69], in order to simulate end plate as well as beam and column flange behavior. The agreement between simulations and test data was satisfactory because both contact and beam elements were adopted to simulate friction and bolt action, respectively. But, so far as the simulation of prying forces is concerned, thick shell analysis is capable to 
simulate the evolution of internal normal stresses required to satisfy equilibrium with prying forces. A rigorous approach to the modeling of bolted connections was adopted later by Gebbeken et al. [70], which discretized bolted tee stubs in a 3D fashion by means of eight-node brick elements, and investigated the contact problem between deformable bodies in a small deformation regime. Comparisons between simulated and measured data were good. However, the parametric study on end plate joints was performed with 2D finite element models, thus limiting the analysis effectiveness. 3D finite element models based on solid and contact elements of the ABAQUS library [71-72] were proposed by Bursi and Leonelli [73] to simulate the rotational behavior of isolated bolted end plate connections.

In this study, a three-dimensional model using the finite element analysis with material non-linearities is introduced. The main purpose of the proposed finite element (FE) model is to simulate the moment-rotation behavior of extended endplate connections subjected to either monotonic or cyclic loads. This model has the ability to be modified easily and then resolved repeatedly to take the different geometric and material parameters that affect the behavior of such joints into account.

More recently Bose, Sarkar and Bahrami [74] used FEA to produce moment rotation curves, Bose, Youngson and Wang [75] reported on 18 full scale tests to compare moment resistance, rotational stiffness and capacity. The latest design method utilises plastic bolt force distribution to create an increased moment connection capacity and reduced column stiffening.

In recent years, large-scale general-purpose finite element codes have developed rapidly and their functions are more and more perfect. This makes it possible to apply finite element analysis on different bolted end-plate connections. Sherbourne and Bahaari [76] used ANSYS 4.4 for finite element analysis of end-plate connections, in addition to the overall behavior of the connection, the contribution of bolts, end-plate and column flange flexibility to the connection rotation was singled out, and the distribution and variation of prying forces was shown. They also used ANSYS 4.4 for finite element analysis on 34 stiffened extended end-plate connections and 19 end-plate connections without stiffener in tension region, and then they gave a single standardized $M$ - $\theta$ function for each of these two connection types by curve fitting $[77,78]$ But their results are comparable only with two-way internal connections, and the version of ANSYS used is low. Now the higher version of ANSYS provides many new functions that can simulate, analyze and compute the mechanical behavior of bolted end-plate connections more accurately.

Many new functions of this finite-element software are used to simulate each component of the connections more accurately. These connections are all originated from familiar multi-story steel frames. During the finite element analysis, the interaction between the end-plate and column flange, as well as geometric and material nonlinearities have been considered and the pretension force of bolts are not applied by initial strains of the conventional method but a new and more appropriate method. Based on the results of FEA, the loading resistance, rotational stiffness and $M-\theta$ relationship of these connections, the tension force distribution of the bolts and the contribution of components to joint rotation have been presented, and the influences of connection details on the connection behavior have been discussed.

The aforementioned studies and others used the time consuming experimental data to develop $M-\theta$ equations, which limits the variation of connection geometry in the test matrix. While some researchers such as Krishnamurthy [79], Ghassemieh et al. [80] and Bahaari and Sherbourne [81-82] developed detailed finite element method (FEM) models for large capacity extended end-plate connections and compared their analysis results with those of experiments, the development of FEM-based model equations was outside the scope of their studies. Summer et al. [83] conducted a series tests on four bolt extended unstiffened and the eight bolt extended stiffened end-plate connections along with a validation study utilizing the finite element method. The accuracy of the FEM and its results are verified by using experimentally obtained $M-\theta$ curves by Srouji et al. [29]. A test matrix with 34 test specimens is introduced by varying the geometric variables of the flush end-plate connection within its practical range from low to intermediate to high values. These test cases were analyzed using the developed FEM model and the resulting $M-\theta$ data were curve fitted to Ramberg-Osgood [33] and Three-Parameter Power model [43-44] equations, and regression equations were developed for the parameters defining these model equations. Finally, predicted $M-\theta$ curves using Ramberg-Osgood and Three-Parameter equations were compared with those obtained from experimental FEM analyses. Recently the time saving technique for the analysis of finite element model of the structure under cyclic loading is mentioned by the Elsayed Mashaly et al. [84] in his literature \& it was proved right by him through carrying out the analysis of a bolted structure.

\section{Acknowlegments}

The bibliography presented in Appendix A is by no means complete but it gives a comprehensive representation of different finite element techniques applied to the analysis of Beam to Column endplate bolted connection. The author wishes to apologize for the unintentional exclusions of missing references and would appreciate receiving comments and pointers to other relevant literature for a future update. 


\section{Appendix A: A Bibliography (1914-2011)}

This bibliography provides a list of literature references on finite element analyses of beam to column endplate connection, theory and applications. The listing presented contains papers published in scientific journals, conference proceedings, manuals and thesis/dissertations, retrospectively to 1914. Entries are grouped into the same sections described in the first and second part of this paper, and sorted according to the use of literature in the paper. In some cases, if a specific paper is relevant to several subject categories, the same reference can be listed under the respective section headings, but the interested reader is expected to consider also areas adjacent to his/her central area of research interest.

\section{References}

[1] Bendixen A. Die methode der alpha-gleichungen zur berechnung yon rahmenkonstruktionen. Berlin, Germany: Springer; 1914.

[2] Cross H. Analysis of continuous frames by distributing fixed-end movements. In: Grinter LB, editor. Numerical methods of analysis in engineering. Successive corrections New York: Macmillan Company; 1949. 1-12.

[3] Monforton GR, Wu TS. Matrix analysis of semi-rigidly connected frames. J Struct Eng 1963; 89(ST6): 3713-42

[4] Livesley RK. Matrix methods of structural analysis. 1st Ed. Oxford: Pergamon Press; 1964.

[5] Lui EM, Chen WF. Steel frame analysis with flexible joints. J Constructional Steel Res 1987; 8: 161-202.

[6] Jaspart JP, Maquoi R. Guidelines for the design of braced frames with semi-rigid connections. J Constructional Steel Res 1990; 16(4): 319-28.

[7] Cabrero JM, Bayo E. Development of practical design methods for steel structures with semi-rigid connections. Eng Structures 2005; 27(8): 1125-37.

[8] Darío Aristizabal-Ochoa J. Second-order slope-deflection equations for imperfect beam-column structures with semi-rigid connections. Eng Structures 2010; 32(8): 2440-54.

[9] Faella C, Piluso V, Rizzano G. Structural steel semirigid connections: theory, design and software. New directions in civil engineering. Boca Raton, Florida: CRC publishers; 2000 (EEUU).

[10] Weynand K. SERICON I - databank on joints building frames. Proc. COST C1 First State of the Art Workshop on Semi-rigid Behaviour of Civil Engineering Structures; 1992, 463-74.

[11] Frye MJ, Morris GA. Analysis of flexibly connected steel frames. Canadian J Civil Eng 1975; 2(3): 280-91.

[12] Chen WF, Kishi N, Matsuoka KG, Nomachi SG. Moment-rotation relation of single double web angle connections. Connections in steel structures: behaviour, strength and design. London: Elsevier Applied Science; 1988.

[13] Yee KL, Melchers RE. Moment-rotation curves for bolted connections. J Struct Eng 1986; 112: 615-35.

[14] Simões da Silva L, Girão Coelho AM. An analytical evaluation of the response of steel joints under bending and axial force. Computers Structures 2001; 79: 873-81.

[15] Lemonis ME, Gantes CJ. Mechanical modeling of the nonlinear response of beamto-column joints. J Constructional Steel Res 2009; 65: 879-90.

[16] European Committee for Standardisation (CEN). Eurocode 3. Design of steel structures, part 1-8: design of joints (EN 1993-18:2005); 2005. Brussels.

[17] Kim J, Ghaboussi J, Elnashai AS. Mechanical and informational modeling of steel beam-to-column connections. Eng Structures 2010; 32(2): 449-58.

[18] Cevik A. Genetic programming based formulation of rotation capacity of wide flange beams. J Constructional Steel Res 2007; 63(7): 884-93

[19] Díaz C, Martí P, Victoria M, Querin OM. Review on the modelling of joint behavior in steel frames. J Constructional Steel Res $2011 ; 67(5): 741-58$

[20] Nethercott D.A., Steel beam to column connections - A review of test data, Construction Industry Research \& Information Association, 1985.

[21] Chen, W.F. (2000), Practical Analysis for Semi-Rigid Frame Design. World Scientific, Singapore.

[22] Wilson WM,Moore HF. Tests to determine the rigidity of riveted joints in steel structures. Bulletin No. 104. Urban: Engineering Experimentation Station, University of Illinois; 1917.

[23] Rathbun JC. Elastic properties of riveted connections. Transactions of the ASCE 1936; 101: $524-63$ [Paper No. 1933].

[24] Bell WG, Chesson E, Munse WH. Static tests on standard riveted and bolted beam-to-column connections. Engineering Experimentation Station, University of Illinois; 1958.

[25] Douty RT, McGuireW. High strength bolted moment connections. Journal of the Structural Division, ASCE 1965; 91(ST2): 101-28.

[26] Sommer WH. Behavior of welded header plate connections. Master's thesis, Ontario (Canada): University of Toronto; 1969.

[27] Ostrander JR. An experimental investigation of end-plate connections. Master of Science thesis. University Saskatchewan; 1970.

[28] Johnstone ND,Walpole WR. Bolted end-plate beam-to-column connections under earthquake type loading. Research Report 81-7. Christchurch (New Zealand): Department of Civil Engineering, University of Canterbury; 1981.

[29] Srouji R, Kukreti AR, Murray TM. Strength of two tension bolt flush end-plate connections. Research Report No. FSEL/MBMA 8303. Norman (OK): Fears Structural Engineering Laboratory, School of Civil Engineering and Environmental Science, University of Oklahoma; 1983.

[30] Azizinamini A, Radziminski JB. Static and cyclic performance of semi-rigid steel beam-to-column connections. Journal of Structural Engineering, ASCE 1989; 115(12): 2979-99.

[31] Frye MJ, Morris GA. Analysis of flexibly connected steel frames. Canadian Journal of Civil Engineering $1975 ; 2$.

[32] Ang KM, Morris GA. Analysis of three-dimensional frames with flexible beam-column connections. Canadian Journal of Civil Engineers 1984; 11:245-54.

[33] Ramberg W, Osgood WR. Description of stress-strain curves by three parameters, Technical Note No. 902. Washington (DC): National Advisory Committee for Aeronautics; 1943.

[34] Packer JA, Morris LJ. A limit state design method for tension region of bolted beam-column connections. The Structural Engineer 1977; 55(10): 446-58

[35] Zoetemeiijer P. Semi-rigid bolted beam-to-column connections with stiffened column flanges and flushend plates. In: Proceedings of the international conference: joints in structural steelwork: The design and performance of semi-rigid and rigid joints in steel and composite structures and their influence on structural behavior. 1981, 2.99-2.118. 
[36] Phillips J, Packer JA. The effect of plate thickness on flush end-plate connections. In: Joints in structural steel work [Proceedings of international conference on joints in steel work]. New York (Toronto): John Wiley and Sons; 1981: 6.77-6.92.

[37] Bijlaard FSK, Zoetemeiijer P. Influence of joint characteristics on the structural performance of frames.In: Pavlovic MN, editor. Steel structures: Recent research advances and their application to design. London (UK): Elsevier Applied Science Publishers, Ltd; 1986: 109-34.

[38] Bjorhovde R, Brozzetti J, Colson A. Connections in steel structures: Behavior, strength and design. London, England: Elsevier Applied Science Publisher; 1988.

[39] Bjorhovde R, Colson A, Brozzetti J. Classification system for beam-to-column connections. Journal of Structural Engineering 1990; 116(11): 3059-76.

[40] Barakat M, Chen WF. Practical analysis of semi-rigid frames. Engineering Journal-American Institute of Steel Construction 1990; 27(2): 54-68.

[41] $\mathrm{Xu}$ L, Sherbourne AN, Grierson DE. Optimal cost design of semi-rigid, low-rise industrial frames. Engineering Journal, AISC 1995; 87-97 (third quarter).

[42] Yee YL, Melchers RE. Moment-rotation curves for bolted connections. Journal of Structural Engineering, ASCE 1986; 112(3): $615-35$.

[43] Kishi N, Chen WF. Moment-rotation relation of top-and seat-angle connections. Structural Engineering Report No. CE-STR-8626. West Lafayette (IN): School of Civil Engineering, Purdue University; 1987.

[44] Kishi N, Chen WF. Moment-rotation semi-rigid connections. Structural Engineering Report No. CE-STR-87-29, West Lafayette (IN): School of Civil Engineering, Purdue University; 1987.

[45] Stark JWB, Bijlaard FSK. Structural properties of connections in steel frames. In: Connections in steel structures: Behaviour, strength, and design. London (UK): Elsevier Applied Science Publishers; 1988: 186-94.

[46] Bose SK, McNeice GM, Sherbourne AN. Column webs in steel beam to column connexions. Part I: formulation and verification. Computers Structures 1972; 2: 253-72.

[47] Krishnamurthy N, Graddy DE. Correlation between 2- and 3-dimensional finite element analysis of steel bolted end-plate connections. Computers Structures 1976; 6(4-5): 381-9.

[48] Sherbourne AN, Bahaari MR. 3D simulation of end-plate bolted connections. J Struct Eng 1996; 120(11): 3122-36.

[49] Bursi OS, Jaspart JP. Benchmarks for finite element modeling of bolted steel connections. J Constructional Steel Res 1997; 43: 1742 .

[50] Bursi OS, Jaspart JP. Calibration of a finite element model for isolated bolted end plate steel connections. J Constructional Steel Res 1997; 44(3): 225-62.

[51] Bursi OS, Jaspart JP. Basic issues in the finite element simulation of extended end plate connections. Computer Structures 1998; 69: 361-82.

[52] Choi CK, Chung GT. Refined three-dimensional finite element model for end-plate connection. J Struct Eng ASCE 1996; 122(11): pp. 1307-16.

[53] Bahaari MR, Sherbourne AN. Behaviour of eight-bolt large capacity endplate connections. Computers Structures 2000; 77: pp.31525.

[54] Sumner EA, Mays TW, Murray TM. End-plate moment connections: test results and finite element method validation. 4th International Workshop on Connections in Steel Structures; 2000. 82-93.

[55] Swanson JA, Kokan DS, Leon RT. Advanced finite element modeling of bolted Tstub connection components. J Constructional Steel Res 2002; 58(5-8): 1015-31.

[56] Citipitioglu AM, Haj-Ali RM, White DW. Refined 3D finite element modeling of partially-restrained connections including slip. J Constructional Steel Res 2002; 58: 995-1013.

[57] Gantes CJ, Lemonis ME. Influence of equivalent bolt length in finite element modeling of T-stub steel connections. Computers Structures 2003; 81: 595-604.

[58] Ju SH, Fan CY, Wub GH. Three-dimensional finite elements of steel bolted connections. Eng Structures 2004; $26: 403-13$.

[59] Tagawa H, Gurel S. Application of steel channels as stiffeners in bolted moment connections. J Constructional Steel Res 2005; 61(12): 1650-71.

[60] Abolmaali A, Matthys JH, Farooqi M, Choi Y. Development of moment-rotation model equations for flush end-plate connections. J Constructional Steel Res 005; 61: 1595-612.

[61] Maggi YI, Gonçalves RM, Leon RT, Ribeiro LFL. Parametric analysis of steel bolted end plate connections using finite element modelling. J Constructional Steel Res 2005; 61: 689-708.

[62] Kukreti AR, Zhou FF. Eight-bolt endplate connection and its influence on frame behaviour. Eng Structures 2006; $28: 1483-93$.

[63] Pirmoz A, Saedi DA, Mazaheri A, Ebrahim DH. Behavior of bolted angle connections subjected to combined shear force and moment. J Constructional Steel Res 2008; 64: 436-46.

[64] Dai XH, Wang YC, Bailey CG. Numerical modelling of structural fire behaviour of restrained steel beam-column assemblies using typical joint types. Eng Structures 2010; 32: 2337-51.

[65] N. Krishnamurthy, D. Graddy, Correlation between 2 and 3-dimensional finite element analysis of steel bolted end-plate connections, Journal of Computer and Structures 6 (1976): 381-389.

[66] A.R. Kukreti, T.M. Murray, A. Abolmaali, End plate connection moment-rotation relationship, Journal of Constructional Steel Research 8 (1987): 137-157.

[67] A.R. Kukreti, T.M. Murray, M. Ghassemieh, Finite element modeling of large capacity stiffened steel tee-hanger connections, Journal of Computer and Structures 32 (2) (1989): 409-422.

[68] C.P. Chasten, L.W. Lu, G.C. Driscoll, Prying and shear in end plate connection design, Journal of Structural Engineering, ASCE 118 (5) (1992): 1295-1311.

[69] A.N. Sherbourne, M.R. Bahaari, 3D simulation of end-plate bolted connections, Journal of Structural Engineering, ASCE 120 (11) (1994): pp. 3122-3136.

[70] N. Gebbeken, H. Rothert, B. Binder, On the numerical analysis of end plate connections, Journal of Constructional Steel Research 30 (1994): 177-196.

[71] ABAQUS User's Manual, vols. 1 and 2, Version 5.4, Hibbitt Karlsson and Sorensen, Pawtreket, RI, 1994.

[72] ABAQUS Theory Manual, Version 5.4, Hibbitt, Karlsson and Sorensen, Pawtreket, RI, 1994.

[73] O.S. Bursi, L. Leonelli, A finite element model for the rotational behavior of end plate steel connections, in: Proceedings of the SSRC Annual Technical Session, Chicago, 1994, 163-175.

[74] Bose B, Sarkar S, and Bahrami M, Finite Element Analysis of unstiffened extended end plate connections, Structural Engineering Review, 3, 1991, 211-224. 
[75] Bose B, Youngson G K, and Wang Z M, An appraisal of the design rules in Eurocode 3 for bolted end plate joints by comparison with experimental results, Proceedings from the Institute of Civil Engineers Structures and Buildings, 1996: 14

[76] Bahaari, M. R. and Sherbourne, A. N. (1997), Finite element prediction of end plate bolted connection behavior II : analytic formulation, Journal of Structural Engineering, Vol. 123, No. 2: 165-175.

[77] Sherbourne, A. N. and Bahaari, M. R. (1994), 3D simulation of end-plate bolted connections, Journal of Structural Engineering, Vol. 120, No. 11:3122-3136.

[78] Sherbourne, A. N. and Bahaari, M. R. (1997), Finite element prediction of end plate bolted connection behavior I : parametric study, Journal of Structural Engineering, Vol. 123, No. 2: 157-164.

[79] Krishnamurthy N. Freash look at bolted end-plate behavior and design. Engineering Journal, AISC 1978; 15(2): 39-49 [second quarter].

[80] Ghassemieh M, Kukreti AR, Murray TM. Inelastic finite element analysis of stiffened end-plate moment connections. Research Report No. FSEL/MBMA 83-02. Norman (OK): Fears Structural Engineering Laboratory, School of Civil Engineering and Environmental Science, University of Oklahoma; 1983.

[81] Bahaari MR, Sherbourne AN. Computer modeling of an extended end-plate bolted connection. Computers and Structures 1994; 52(5): 879-93.

[82] Bahaari MR, Sherbourne AN. Structural behavior of end-plate bolted connections to stiffened columns. Journal of Structural Engineering, ASCE 1996; 122(8): 926-35.

[83] Summer EA, Mays TW,Murray TM. End-plate moment connections: test results and finite element method validation. In: Connections in steel structures [The fourth international workshop in steel structures]. 2000.

[84] Elsayed Mashaly, Mohamed El-Heweity, Hamdy Abou-Elfath, Mohamed Osman, Finite Element Analysis of beam to column joints in steel frames under cyclic loading, Alexandria Engineering Journal (2011) 50: 91-104. 